UDC $633.11+575.21$

\title{
RELATIONSHIPS BETWEEN CANOPY ASSIMILATION SURFACE CAPACITY TRAITS AND GRAIN PRODUCTIVITY OF WINTER WHEAT GENOTYPES UNDER DROUGHT STRESS
}

\author{
V. V. Morgun, G. A. Priadkina, O. O. Stasik, O. V. Zborivska \\ Institute of Plant Physiology and Genetics, \\ National Academy of Sciences of Ukraine, 31/17, Vasylkivska Str., Kyiv, 03022, Ukraine \\ e-mail: galpryadk@gmail.com
}

Received March 29, 2019 / Received April 25, 2019 / Accepted July 19, 2019

\begin{abstract}
Aim. A comparative analysis of several traits of the capacity of the assimilation apparatus of 10 varieties and 2 lines of winter wheat from Ukraine, under conditions of insufficient precipitation and elevated air temperature during the period, when the reproductive organs formed (GS 30-49), in order to search for phenotypic markers associated with high productivity. Methods. Field, morphometric, spectrophotometric and statistical methods were used. Results. The maximum difference in yield between varieties and lines, which grew under conditions of insufficient water supply and high temperatures in April and May of growing season 2017/2018, was $24.7 \%$. Under these conditions, the highest grain productivity was observed for the new varieties Pochayna, Hospodarka and Kyivska 17 (8.60-8.73 t/ha) and a high canopy leaves chlorophyll index at late stages of ontogenesis (0.38-0.48 $\mathrm{g}$ chlorophyll $/ \mathrm{m}^{2}$ at milky-wax ripeness). This was opposed to varieties Smuhlianka, Poradnytsia and the line UK 392/15 with the lowest yield (7.00-7.25 t/ha) and assimilation surface at this stage $\left(0.07-0.17 \mathrm{~g}\right.$ chlorophyll $\left./ \mathrm{m}^{2}\right)$. At the flowering stage (anthesis) the most productive varieties exceeded the least productive ones, on average, by $30 \%$ in leaves fresh weight of the canopy, by $24 \%$ in content of total $(a+b)$ chlorophyll and by $60 \%$ in canopy chlorophyll index. At milky-wax ripeness, the differences between these varieties increased significantly - up to $136 \%$ in leaf fresh weight of canopy, $57 \%$ in chlorophyll content and $350 \%$ in canopy leaves chlorophyll index. A close positive correlation $(\mathrm{r}=0.69-0.77, \mathrm{P}<0.01)$ between the canopy photosynthetic apparatus traits at milky-wax ripeness with the yield of varieties and lines of winter wheat under drought and high temperature stress was found. Conclusions. The results show that the leaves fresh weight of canopy and canopy leaves chlorophyll index can be used as markers of grain productivity of winter wheat under drought stress, as well as for the possible development of molecular genetic criteria of breeding, based on these phenotypic characteristics.
\end{abstract}

Keywords: Triticum aestivum L., canopy assimilation surface, chlorophyll index, yield.

DOI: https://doi.org/10.15407/agrisp6.02.018

\section{INTRODUCTION}

The strategic value of wheat in food safety of many countries is related to the fact that this crop covers over a quarter of the global crop production volume. Wheat also remains a major source of dietary calories and proteins in Eastern Europe and Russia (28-29\%), and South Asia (20-24\%) and high-income countries (20\%) [1]. Most modern, highly productive varieties of winter wheat have a high genetic potential, which, however, may remain

(C) V. V. MORGUN, G. A. PRIADKINA, O. O. STASIK, O. V. ZBORIVSKA, 2019 unrealized under unfavorable conditions. This considerable difference between potential productivity and actual yield observed $[2,3]$ necessitates further studies of phenotypic variability of plants under field conditions. The evaluation of phenotypic variability of varieties is mainly conducted using yield or yield components, morphological parameters and duration of phenological stages $[4,5]$. Since increasing photosynthetic capacity and efficiency is considered the basis for raising yield potential of wheat [6], studying the variability in assimilation surface may contribute to the breeding for increase of wheat productivity, too. The significant role of the photosynthetic 
apparatus in creating yield determines its relevance for further study [7].

One of the main abiotic stressors, limiting the yield of agricultural crops in the whole world, is drought. Soft winter wheat is sensitive to insufficient moisture. The number of productive stems decreases under drought conditions, the reproductive processes of forming spike elements, pollen fertility and formation and filling of kernels are disrupted. Drought facilitates the decrease in the activity of the photosynthetic apparatus and faster yellowing of leaves due to inhibition and eventual destruction of chlorophyll synthesis [8-10]. The main reason of inhibition of photosynthetic processes under drought conditions is limiting the diffusion of $\mathrm{CO}_{2}$ into the carboxylation centers due to decreased conductance of stomata and mesophyll cells [11]. The urgency of creating highly productive drought-tolerant/resistant varieties of wheat is confirmed by the data of meteorological observations, proving more frequent droughts and elevated air temperature worldwide [12-14].

Most traits of wheat, discussed in the literature as markers of tolerance to drought and high temperatures, are related to different traits of the functional state of the photosynthetic apparatus [6]. Recent scientific data demonstrate that the preservation of canopy photosynthetic activity after anthesis ensures better conditions for grain filling $[7,15,16]$. In particular, it was demonstrated that highly productive varieties and lines of wheat have more long-term functioning of the photosynthetic apparatus $[17,18]$.

Our previous studies have shown that varieties with a larger canopy assimilation surface at milky-wax ripeness (MWR) stage had a higher yield. A significant correlation between canopy leaves chlorophyll index, estimated by the total amount of green leaves chlorophyll of plants per $\mathrm{m}^{2}$, at MWR and yield $(\mathrm{r}=0,64-0,84$, $\mathrm{P}<0.05)$ was observed in years with different meteorological conditions [19]. In contrast to the conditions of the previous two-year experiments, during the spring growing season of wheat in 2018, the amount of precipitation in April and May was significantly less: respectively, by 3.6-4.2 and 1.1-4.4 times. A significant increase in air temperature was also observed during these two months in 2018.

Thus, both elevated air temperature and insufficient natural water supply allowed analyzing the characteristics of the assimilation surface and the productivity of different genotypes of winter wheat under drought conditions during the period, when the reproductive organs of winter wheat formed. The identification of phenotypic traits, related to high grain productivity of winter wheat under drought conditions (and the connected elevated air temperature) is one of the stages for further elaboration of the methods of breeding selections for tolerance or resistance to this stress factor. The purpose of this work was to link canopy assimilation surface capacity traits to grain productivity in order to evaluate winter wheat genotypes under drought stress conditions.

\section{MATERIALS AND METHODS}

Ten Ukrainian middle-early varieties of winter wheat (Triticum aestivum L.), viz. Pochayna, Hospodarka, Krasnopilka, Poradnytsia, Kyivska 17, Dobroslava, Darynka Kyivska, Perlyna Lisostepu, Smuhlianka and Shchedrivka Kyivska, and two Ukrainian new middle-early lines: UK 392/15 and UK 2127/15 were studied at the winter wheat variety-trial fields of the experimental farm of the Institute of Plant Physiology and Genetics, NAS of Ukraine (Hlevakha, Kyiv Region, 50¹6'S, 30¹9'E; $197 \mathrm{~m}$ above sea level) under natural moisture conditions. One of two of old varieties - Smuhlianka (released in 2004) - was used as standard (second old variety used was Perlyna Lisostepu, 2001), and others varieties are relatively new (released 2016-2018).

All experimental plots were in one field with plot locations as for genetic research (a systematic block design). The area of an individual plot was $10 \mathrm{~m}^{2}$ $(1.5 \mathrm{~m} \times 6.67 \mathrm{~m})$ in three replications. There was $1 \mathrm{~m}$ spacing between plots and each replication was separated by $0.5 \mathrm{~m}$ space. All winter wheat varieties and lines was sown in the third decade of September, at a sowing density of 5.5-6 million seeds per hectare. In the experimental plots the soil under the canopy was light gray, light loamy podzol. During the vegetation, $145 \mathrm{~kg}$ of nitrogen and $90 \mathrm{~kg}$ of phosphorus and potassium each per hectare were introduced. In the fall, fertilization with $\mathrm{N}, \mathrm{P}$ and $\mathrm{K}(\mathrm{N}: \mathrm{P}: \mathrm{K}=16 \%)$ was applied under pre-sow ploughing. $\mathrm{N}$ fertilization (urea, $\mathrm{N}=$ $=34 \%$ ) was applied on frozen ground in spring and at booting (40-42 SG). Herbicides were used in the fall (4 leaves unfolded, 21-22 SG) and in spring (stem elongation, SG 35-39), fungicide at stem elongation (SG 35-39), insecticide at ear emergence (SG 54-56).

The spring-summer vegetation of plants in the growing season of 2017/2018 was under conditions of elevated air temperature, especially in December, April and May, and in addition, in April and May there was 
insufficient soil moisture due to a low amount of precipitation during this period (Table 1).

In April 2018, an insignificant amount of precipitation (from 1 to $6 \mathrm{~mm}$ per day) fell only three times a month. In April, the average monthly air temperature exceeded the climatic norm by almost $4{ }^{\circ} \mathrm{C}$, and on some days - by $8-9{ }^{\circ} \mathrm{C}$. In May, it exceeded the climatic norm by over $3{ }^{\circ} \mathrm{C}$, and in the first decade of May - on average by $7{ }^{\circ} \mathrm{C}$.

A hydrothermal coefficient, which is calculated as the ratio of precipitation amount per month, in mm, multiplied by 10 , to the sum of temperatures per month, in ${ }^{\circ} \mathrm{C}$, was 0.20 in April and 0.67 in May (Fig. 1). According to Selianinov classification, natural provision of the soil moisture in the first month corresponds to a very dry zone $(<0.4)$ and in the second month - dry zone (0.7-0.4) [21]. Therefore, during the period, when the reproductive organs of winter wheat formed (GS $30-49$ ), the genotypes of winter wheat in 2018 were under drought stress conditions.

The observations of growing stages on external morphological changes of the already formed organs were

Table 1. Weather conditions of the vegetation period of winter wheat in 2017/2018, with a drought and high temperature period in April/May [20]

\begin{tabular}{l|c|c|c|c}
\hline \multirow{2}{*}{ Month } & \multicolumn{2}{|c|}{ Temperature* } & \multicolumn{2}{c}{ Precipitation } \\
\cline { 2 - 5 } & $\begin{array}{c}\text { actual, } \\
{ }^{\circ} \mathrm{C}\end{array}$ & $\begin{array}{c}\text { differen- } \\
\text { ce from } \\
\text { the } \\
\text { norm, } \\
{ }^{\circ} \mathrm{C}^{* *}\end{array}$ & $\begin{array}{c}\text { actual, } \\
\mathrm{mm}\end{array}$ & $\begin{array}{c}\% \text { from } \\
\text { the } \\
\text { norm** }\end{array}$ \\
\hline \multicolumn{4}{c}{2017} \\
\hline September & 16.4 & +2.2 & 43 & 75 \\
October & 8.4 & 0 & 81 & 198 \\
November & 3.3 & +1.4 & 46 & 92 \\
December & 1.6 & +3.9 & 133 & 296 \\
\hline \multicolumn{4}{|c}{2018} \\
January & -2.4 & +1.1 & 40 & 111 \\
February & -3.8 & -0.8 & 40 & 103 \\
March & -1.9 & -3.7 & 82 & 222 \\
April & 13.1 & +3.8 & 8 & 17 \\
May & 18.8 & +3.3 & 39 & 68 \\
June & 20.6 & +2.1 & 111 & 135 \\
July & 21.4 & +0.9 & 87 & 123 \\
\hline
\end{tabular}

Note: * - the actual data from nearest to the experimental fields meteorological station; ** - long-term (1881-2017) daily mean air temperature and monthly precipitation means. conducted every 3-4 days, during a period from tillering (SG20) to full ripening (SG93) [22]. The fresh weight of some organs, namely of leaves, spikes and stems (including leaf sheaths) was determined on 20 (main and lateral) shoots selected in sequence in four replications. The determination of phytometric and pigment parameters was carried out in the mean samples (20 shoots) twice (at anthesis and at MWR), and yield components (at full ripeness, FR). To determine the dry weight of the aboveground organs $5 \mathrm{~g}$ of the fresh weight of leaves and $10 \mathrm{~g}$ spikes and stems were selected and tested in three replications. A determination of the canopy density was carried out 3 times: at anthesis, at MWR and FR. To determine the canopy density per $\mathrm{m}^{2}$, the number of shoots on four halfmeter segments in different rows per plot was counted in four replications. Than an average number of plants per 0.5 running meter was multiplied in 2 and with the length of the row. The figure than was multiplied in 10 (the number of rows per plot) and divided in $10 \mathrm{~m}^{2}$ (the area of each plot). Since these coefficients are reciprocally reduced, only the first procedure can be used to calculate the number of shoots per $\mathrm{m}^{2}$.

The content of photosynthetic pigments (chlorophylls a and $b$ and total carotenoids) in green leaves was determined by the non-maceration method via extraction of pigments from the leaves using dimethyl sulfoxide, according to Wellburn [23]. The optical density of solutions was determined using a spectrophotometer (Specord 200, AnalyticJena, Germany) in a e $1 \mathrm{~cm}$ thik cuvette at 649 and $665 \mathrm{~nm}$ absorbance for chlorophylls a and $b$ respectively and $480 \mathrm{~nm}$ for total carotenoids. The content of leaf pigments was expressed in $\mathrm{mg} / \mathrm{g}$ of fresh weight. The number of leaves in an average sample was 10 leaves in three analytical replicates. The canopy leaves chlorophyll index, characterizing the total amount of chlorophyll therein ( $\mathrm{g}$ of chlorophyll $/ \mathrm{m}^{2}$ ), was determined as the product of chlorophyll content and average (from 20 shoots) leaves fresh weight and number of shoots (main and lateral) per $\mathrm{m}^{2}$ of soil [24]. The yield components (weight grains per spike, number of kernels per spike, thousand-kernel weight and harvest index) were determined at full grain ripeness in 20 winter wheat plants, selected from each plot, on all (main and side) shoots. The yield was determined by the direct harvesting method, again in 3 replications.

All data obtained were subjected to statistical analysis using statistical software of Microsoft Excel (2013) according to methods described by Dospekhov [25]. The results are expressed as means with 
standard error $(\mathrm{m} \pm \mathrm{SEM})$. Data were processed using analysis of variance (ANOVA) and the Tukey test at $5 \%$ probability level $(\mathrm{P}<0.05)$. Linear correlation was determined using the Pearson correlation coefficient.

\section{RESULTS AND DISCUSSION}

The yield of 10 Ukrainian varieties and 2 new lines of winter wheat, affected by unfavorable conditions (drought and high temperatures) during the during the period, when the reproductive organs formed, fluctuated from 7.00 to $8.73 \mathrm{t} / \mathrm{ha}$, and in 7 out of 12 genotypes it equaled or exceeded $8 \mathrm{t} / \mathrm{ha}$ (Table 2 ).

The highest yield (8.60-8.73 t/ha) was by the new varieties Pochayna, Hospodarka and Kyivska 17, while Smuhlianka, Poradnytsia and line UK 392/15 had a lower yield (7.25, 7.12 and $7.00 \mathrm{t} / \mathrm{ha}$, respectively). One of the highly productive varieties, Hospodarka, was characterized by the highest number of kernels per spike $(38.3 \pm 1.73)$ and better filling of kernels (1000 grains weight was $52.5 \pm 0.83 \mathrm{~g}$ ). The highly productive variety Kyivska 17, however, had a low grain productivity per spike with a low number of kernels per it $(1.44 \pm 0.07 \mathrm{~g}$ and $33.4 \pm 1.28$ kernels, respectively) and thousand-kernel weight $(42.6 \pm 0.93 \mathrm{~g})$, but it formed the canopy with higher density of plants (+33\%), than Hospodarka (Fig. 2). Therefore, high yield of highly productive genotypes was apparently due to higher filling capacity of plants and due to higher performance of an individual spike. All three genotypes with the least yield had no significant differences in the

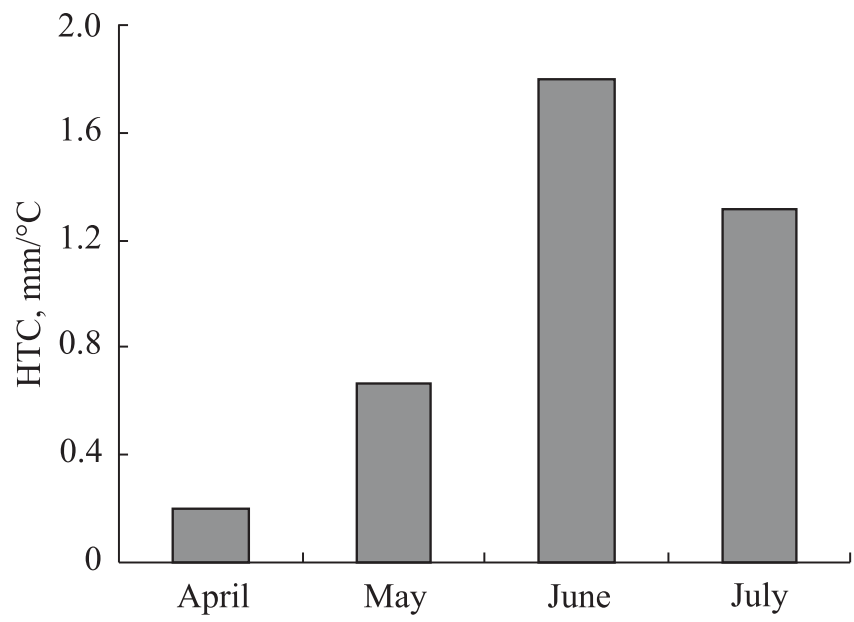

Fig. 1. Hydrothermal coefficient, $\mathrm{mm} /{ }^{\circ} \mathrm{C}$, during the springsummer vegetation period of winter wheat in 2018

density of plant stand and number of kernels from the spike, but differed in their filling (Table 2).

The density of productive shoots in the canopies of the studied varieties and lines fluctuated from 547 to 747 shoots $/ \mathrm{m}^{2}$ at anthesis and from 417 to 570 shoots $/ \mathrm{m}^{2}$ at full ripeness (Fig. 2). The number of shoots did not correlate with yield to any of the studied stages (low correlation coefficients, data is not presented). The highest $\left(570 \pm 18\right.$ shoots $\left./ \mathrm{m}^{2}\right)$ and lowest $(417 \pm$ \pm 24 ) density of the canopy at full ripeness were observed in the group of the most productive varieties, respectively Kyivska 17 and Horodnytsia (Fig. 2). It should be noted that during the period from anthesis to full ripeness, the density of productive stems in the

Table 2. The yield and yield components of winter wheat varieties and lines, Kyiv Region, Hlevakha, 2018. Values are means and standard error of the mean, $(\mathrm{m} \pm \mathrm{SEM})$. (Number of plots for yield determination $\mathrm{N}=3$, number of replicates for yield components $n=20$ plants)

\begin{tabular}{l|c|c|c|c|c}
\hline \multirow{2}{*}{\multicolumn{1}{c|}{ Variety }} & \multirow{2}{*}{ Yield, t/ha } & \multicolumn{2}{|c|}{ Weight, g, of } & \multirow{2}{*}{$\begin{array}{c}\text { Number of ker- } \\
\text { nels per spike }\end{array}$} & Harvest index \\
\cline { 3 - 5 } & & grains per spike & 1000 grain & \\
\hline Pochayna & $8.73 \pm 0.12 \mathrm{a}$ & $1.64 \pm 0.08 \mathrm{a}$ & $47.7 \pm 1.27 \mathrm{a}$ & $34.2 \pm 1.40 \mathrm{a}$ & $0.52 \pm 0.01 \mathrm{a}$ \\
Kyivska 17 & $8.60 \pm 0.08 \mathrm{a}$ & $1.44 \pm 0.07 \mathrm{~b}$ & $42.6 \pm 0.93 \mathrm{~b}$ & $33.4 \pm 1.28 \mathrm{a}$ & $0.55 \pm 0.01 \mathrm{~b}$ \\
Hospodarka & $8.60 \pm 0.26 \mathrm{a}$ & $2.03 \pm 0.10 \mathrm{c}$ & $52.5 \pm 0.83 \mathrm{c}$ & $38.3 \pm 1.73 \mathrm{~b}$ & $0.53 \pm 0.01 \mathrm{a}$ \\
UK 2127/15 & $8.27 \pm 0.10 \mathrm{ab}$ & $1.45 \pm 0.07 \mathrm{~b}$ & $37.1 \pm 0.06 \mathrm{~d}$ & $38.3 \pm 1.46 \mathrm{~b}$ & $0.54 \pm 0.01 \mathrm{ab}$ \\
Shchedrivka Kyivska & $8.20 \pm 0.12 \mathrm{~b}$ & $1.53 \pm 0.08 \mathrm{~b}$ & $47.8 \pm 0.88 \mathrm{a}$ & $31.5 \pm 1.42 \mathrm{a}$ & $0.50 \pm 0.02 \mathrm{a}$ \\
Darynka Kyivska & $8.08 \pm 0.06 \mathrm{~b}$ & $1.63 \pm 0.09 \mathrm{a}$ & $48.9 \pm 0.58 \mathrm{a}$ & $33.0 \pm 1.52 \mathrm{a}$ & $0.51 \pm 0.01 \mathrm{a}$ \\
Dobroslava & $7.95 \pm 0.15 \mathrm{~b}$ & $1.49 \pm 0.06 \mathrm{~b}$ & $46.7 \pm 0.66 \mathrm{a}$ & $31.8 \pm 1.12 \mathrm{a}$ & $0.52 \pm 0.01 \mathrm{a}$ \\
Krasnopilka & $7.85 \pm 0.22 \mathrm{bc}$ & $1.48 \pm 0.08 \mathrm{~b}$ & $46.8 \pm 0.92 \mathrm{a}$ & $31.2 \pm 1.42 \mathrm{a}$ & $0.54 \pm 0.01 \mathrm{ab}$ \\
Perlyna Lisostepu & $7.38 \pm 0.07 \mathrm{~d}$ & $1.55 \pm 0.07 \mathrm{~b}$ & $44.9 \pm 1.30 \mathrm{e}$ & $35.3 \pm 1.75 \mathrm{~b}$ & $0.50 \pm 0.01 \mathrm{a}$ \\
Smuhlianka & $7.25 \pm 0.16 \mathrm{~d}$ & $1.63 \pm 0.09 \mathrm{a}$ & $49.9 \pm 0.86 \mathrm{f}$ & $32.1 \pm 1.64 \mathrm{a}$ & $0.51 \pm 0.01 \mathrm{a}$ \\
Poradnytsia & $7.12 \pm 0.09 \mathrm{~d}$ & $1.55 \pm 0.08 \mathrm{~b}$ & $44.6 \pm 0.90 \mathrm{~g}$ & $34.1 \pm 1.48 \mathrm{a}$ & $0.54 \pm 0.01 \mathrm{ab}$ \\
UK 392/15 & $7.00 \pm 0.06 \mathrm{de}$ & $1.42 \pm 0.07 \mathrm{~b}$ & $40.9 \pm 0.88 \mathrm{~h}$ & $34.3 \pm 1.59 \mathrm{a}$ & $0.52 \pm 0.01 \mathrm{a}$ \\
\hline
\end{tabular}

Note: the values indicated with the same Latin letters, are not statistically significant $(\mathrm{P}<0.05)$. 
MORGUN et al.

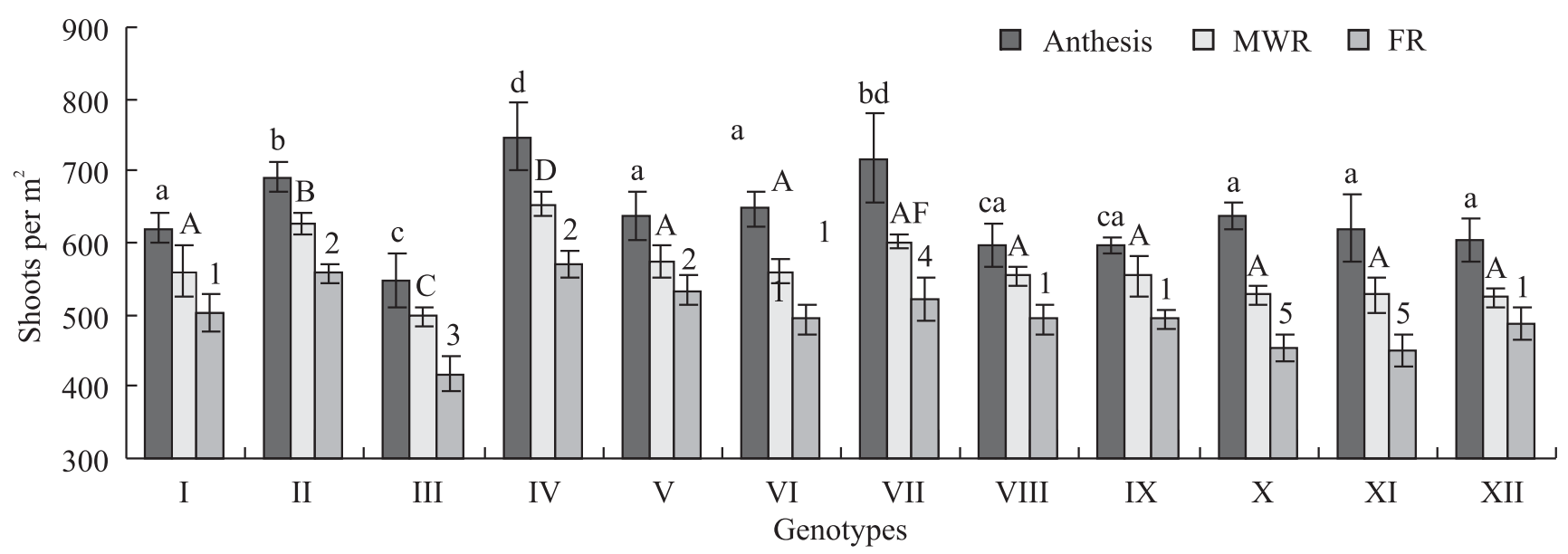

Fig. 2. The dynamics of changes in the density of shoots, shoots per $\mathrm{m}^{2}$, of winter wheat varieties and lines at anthesis, at milky-wax ripeness (MWR) and full ripeness (FR) of the kernel in the growing season of 2017/2018. Here and in Fig. 3 the varieties and lines are indicated as follows: I - Pochayna, II - Kyivska 17, III - Hospodarka, IV - UK 2127/15, V - Shchedrivka Kyivska, VI - Darynka Kyivska, VII - Dobroslava, VIII - Krasnopilka, IX - Perlyna Lisostepu, X - Smuhlianka, XI - Poradnytsia, XII - UK 392/15; the values indicated with the same Latin letters and numbers, are not statistically significant $(\mathrm{P}<0.05)$ : lowercase and letters uppercase, resp., at anthesis and at MWR, numbers - at FR

canopy decreased by $16-30 \%$, reflecting rather considerable excessiveness of productive bushiness. The degree of reduction of productive stems at these phases had a low correlation with the yield, too $(\mathrm{r}=-0.30)$.

The highest difference in yield $(24.7 \%)$ between studied varieties and lines, under conditions of high temperature and drought may be explained by the differences in their potential productivity, as well as differences resistance to unfavorable factors. Photosynthesis is one of the processes of the plant organism that is most sensitive to drought. Water deficiency causes considerable damage to the photosynthetic apparatus and thus decreases carbon assimilation [26-28]. Moreover, under drought conditions, the demand for assimilates, which are necessary for the functioning of protective mechanisms and additional respiration costs, increases. In particular, when photoassimilates are significantly reduced, nonstructural carbohydrates are consumed for cellular survival, including respiratory metabolism and osmotic adjustment [29]. There is also an increased need for additional synthesis of some metabolites, for example, sugars, organic acids, low-molecular-weight osmolytes for the protection of plants from stress [29-31]. Taking the above mentioned into consideration, we have analyzed the changes in traits, characterizing the canopy assimilation surface of winter wheat genotypes under drought conditions during the period GS 30-49.

The area of the canopy, capable of $\mathrm{CO}_{2}$ assimilation, may be characterized by fresh weight of green leaves from a unit area of canopy. It is determined by leaves weight per shoot and the number of shoots per $\mathrm{m}^{2}$. The leaf fresh weight of the studied winter wheat genotypes per $\mathrm{m}^{2}$ at anthesis, varied from 457 to $845 \mathrm{~g} / \mathrm{m}^{2}$ (Fig. 3,a). For the most productive varieties and lines this value exceeded that of the least productive varieties and lines by $30 \%$ on average. At milky-wax ripeness, leaf fresh weight of the more productive genotypes fluctuated from 119 to $219 \mathrm{~g} / \mathrm{m}^{2}$, whereas of less productive ones - from 55 to $100 \mathrm{~g} / \mathrm{m}^{2}$ (by $136 \%$ ). Thus, the differences between genotypes for this index were most expressed at last stage.

The total $(a+b)$ chlorophyll content in the leaves of the investigated varieties and lines of winter wheat at anthesis fluctuated in the range of $3 \mathrm{mg} / \mathrm{g}$ of fresh weight, except for three genotypes (Fig. $3, b$ ). It was lower (2.51-2.88 mg/g of fresh weight) for varieties Darynka Kyivska, Dobroslava, Poradnytsia, and UK $392 / 15$. At milky-wax ripeness the total chlorophyll content for three highly productive varieties and lines $(2.28 \pm 0.01,2.20 \pm 0.06$ and $2.62 \pm 0.04 \mathrm{mg} / \mathrm{g}$ of fresh weight, respectively) exceeded the values of the least productive ones $(1.72 \pm 0.06,1.21 \pm 0.04$ and $1.58 \pm 0.17 \mathrm{mg} / \mathrm{g}$ of fresh weight, respectively) by $57 \%$. It proves that the differences between genotypes by chlorophyll content were also more expressed in late stages of ontogenesis. Total leaf carotenoids content for most varieties and lines of winter wheat at anthesis was $0.50 \mathrm{mg} / \mathrm{g}$ of fresh weight, minimum value for variety Poradnytsia $(0.44 \mathrm{mg} / \mathrm{g} \pm 0.02)$, maximum 

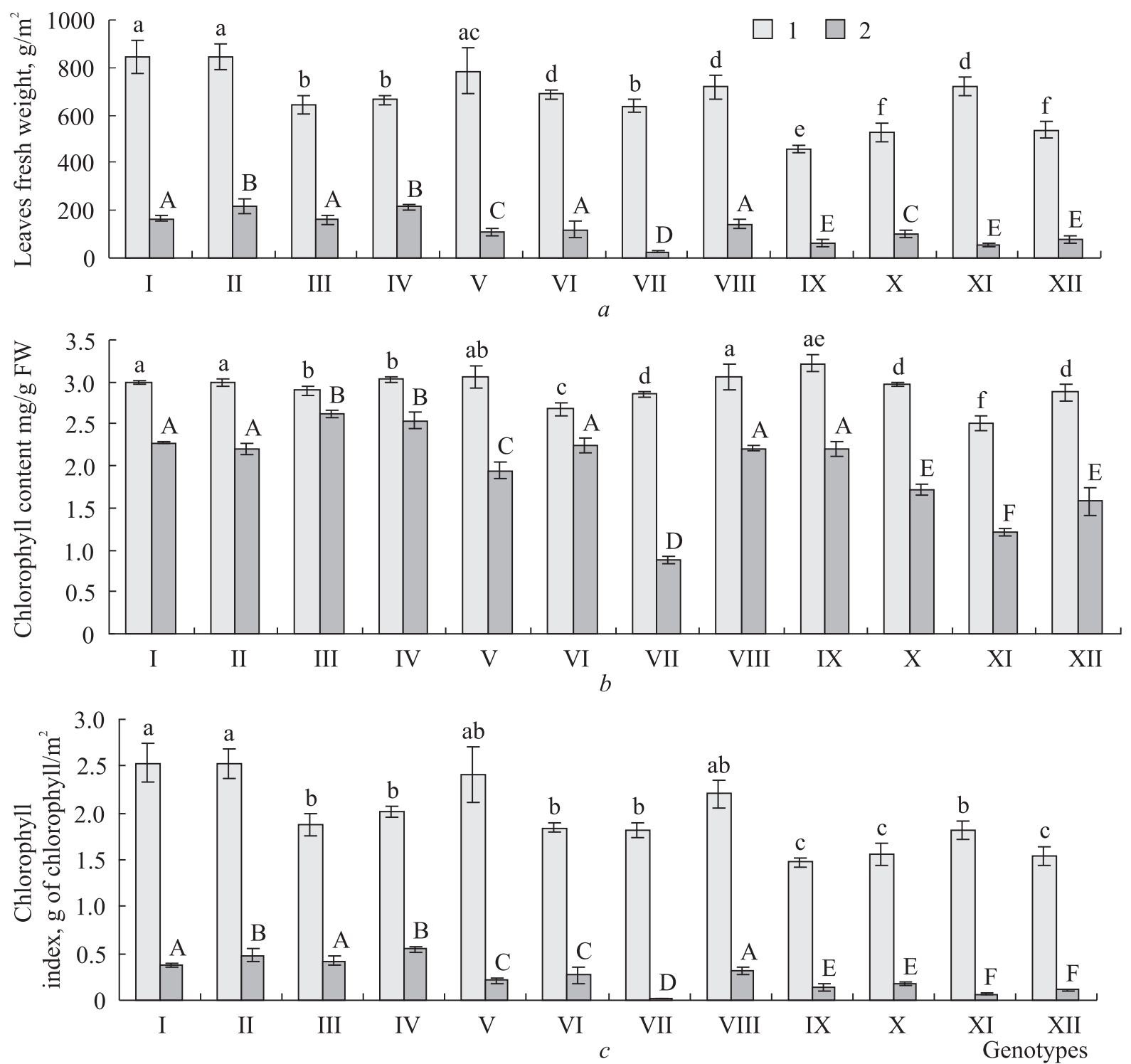

Fig. 3. The traits of canopy assimilation surface capacity of winter wheat genotypes at anthesis (1) and milky-wax ripeness of grain (2): $a$ - fresh weight (FW) of green leaves of winter wheat plants per $\mathrm{m}^{2}, \mathrm{~g} / \mathrm{m}^{2}, b$ - total $(a+b)$ chlorophylls content in green leaves, $\mathrm{mg} / \mathrm{g}$ fresh weight, $c$ - chlorophyll index (total amount of chlorophyll) of green leaves of winter wheat plants per $\mathrm{m}^{2}$, g chlorophyll $/ \mathrm{m}^{2}$. Growing season 2017/2018. The values indicated with the same Latin letters, are not statistically significant $(\mathrm{P}<0.05)$ : lowercase letters - at anthesis, uppercase - at MWR

one for Hospodarka $(0.61 \mathrm{mg} / \mathrm{g} \pm 0.01)$, at milky-wax ripeness the total carotenoids content varied from 0.27 to $0.57 \mathrm{mg} / \mathrm{g}$. The content of this group of photosynthetic pigments is significantly less than that of chlorophyll (16-20\% at first stage and $22-31 \%$ at second). Since no specific patterns of carotenoids influence with productivity were revealed, the data on this content were not presented here.

The highest chlorophyll index of canopy leaves (the total amount of chlorophyll in the leaves of wheat plants per $\mathrm{m}^{2}$ of soil) at anthesis was 2.4-2.5 g chlorophyll/ $\mathrm{m}^{2}$, the least - about 1.5 (Fig. $3, \mathrm{c}$ ). The dif- ference between the most contrasting genotypes Kyivska 17 and UK 2127/15 (0.48-0.54 g of chlorophyll $\left./ \mathrm{m}^{2}\right)$ and Dobroslava, Perlyna Lisostepu, Smuhlianka, Poradnytsia, and UK 392/15 (0.02-0.17 g of chlorophyll $\left./ \mathrm{m}^{2}\right)$ at milky-wax ripeness increased considerably: 3.5 times on average.

The statistical analysis of the traits, characterizing canopy assimilation surface, demonstrated that the variability of leaves fresh weight and their chlorophyll traits at anthesis was average: $7-19 \%$ (Table 3). The variability of all investigated traits at milky-wax ripeness increased: variation coefficients fluctuated from 

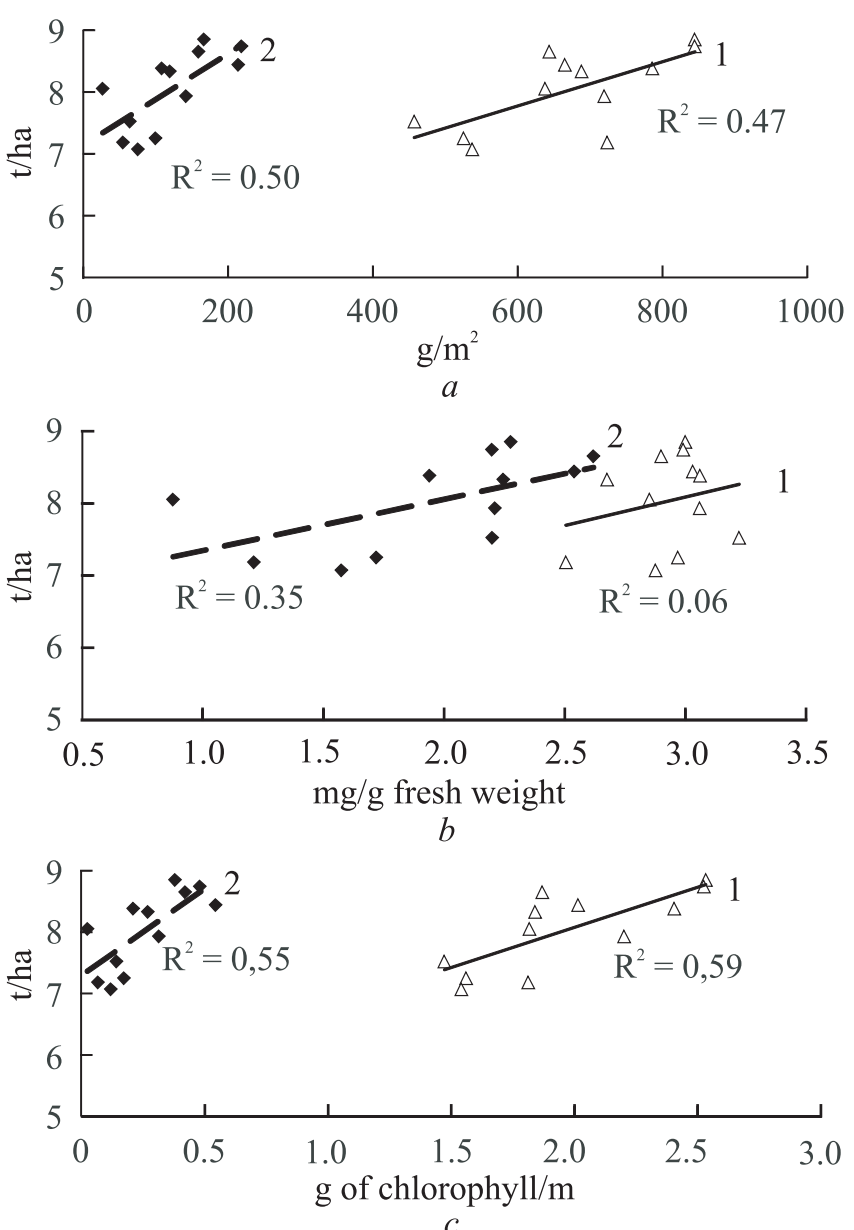

Fig. 4. The dependence of winter wheat yield on the fresh weight of green leaves of winter wheat plants per $\mathrm{m}^{2}, \mathrm{~g} /$ $\mathrm{m}^{2},(a)$, chlorophyll content, $\mathrm{mg} / \mathrm{g}$ of fresh weight, $(b)$, chlorophyll index of its canopy, $\mathrm{g}$ of chlorophyll $/ \mathrm{m}^{2},(c)$ at anthesis (1) and milky-wax ripeness (2). Growing season $2017 / 2018$

Table 3. The coefficients of variation ( \%), of canopy assimilation surface traits of winter wheat genotypes at anthesis and milky-wax ripeness of grain

\begin{tabular}{l|c|c}
\hline \multirow{2}{*}{$\begin{array}{l}\text { Traits of canopy assimilation } \\
\text { surface }\end{array}$} & \multicolumn{2}{|c}{ Growth stages } \\
\cline { 2 - 3 } & anthesis & $\begin{array}{c}\text { milky-wax } \\
\text { ripeness of } \\
\text { grain }\end{array}$ \\
\hline $\begin{array}{l}\text { Total chlorophyll content } \\
\text { of green leaves }\end{array}$ & 7 & 27 \\
$\begin{array}{l}\text { Fresh weight of green leaves } \\
\text { of winter wheat plants per } \mathrm{m}^{2} \\
\begin{array}{l}\text { Chlorophyll index of green } \\
\text { leaves of winter wheat plants } \\
\text { per } \mathrm{m}^{2}\end{array}\end{array}$ & 18 & 51 \\
\hline
\end{tabular}

27 to $62 \%$. Thus, at this stage their variability became significant [25].

To establish whether the difference in productivity of varieties and lines of wheat was related to the variability of the investigated traits of photosynthetic apparatus, the closeness of their correlation with the grain productivity was analyzed (Fig. 4). Significant correlation between total chlorophyll content and yield $\left(\mathrm{R}^{2}=0.06\right.$ and 0.35$)$ not was found (Fig. 4, b). The fresh weight of green leaves of winter wheat plants per $\mathrm{m}^{2}$ (Fig. 4, a) at anthesis and milky-wax ripeness were strongly correlated to yield (respectively, $R^{2}=0.47$ and 0.50 ). The coefficients of determination between total chlorophyll amount and a canopy grain productivity at both stages were even higher: $\mathrm{R}^{2}=0.59$ and 0.55 (Fig. 4, c).

The correlations analysis demonstrated that chlorophyll index of winter wheat leaves positive related to the number of kernels per $\mathrm{m}^{2}$, too (Table 4).

Thus, we found that the varieties and lines of wheat with a high chlorophyll index (higher than $2 \mathrm{~g}$ of chlorophyll $/ \mathrm{m}^{2}$ at anthesis and 0.4 at milky-wax ripeness) had a higher yield (Fig. 3, c, Table 2). The relation between the (sub)optimal or increased functioning of the assimilation apparatus and the realization of genetic yield potential of wheat was also noted by other researchers [32-34]. The highest yield of genotypes with a high chlorophyll index at anthesis may be related to the capability of accumulating photoassimilates in stems $[35,36]$. On one hand, this accumulation of the «excess» of assimilates in stems may promote the increasing of rate of photosynthesis at anthesis, when the demand for them from the spike is still not high [7]. On the other hand, at late stages of ontogenesis, nonstructural carbohydrates that accumulated at anthesis in the stem, may be the additional source of assimilates for grain filling [37, 38].

Higher yield of varieties with a higher chlorophyll index at milky-wax ripeness may be related to longer maintenance of active functioning of the canopy photosynthetic apparatus (i.e. delaying senescence), at later stages of the vegetation period. The fact that the delay in the senescence of leaves promotes elevated yield is demonstrated by the finding that transgenic tobacco plants perform better/longer, with a higher capacity of synthesizing cytokinins, and inhibition of the expression of specific senescence genes at the same time [39]. It was established that mutants lines of durum wheat with delayed leaf senescence, selected from 
Table 4. Correlation coefficients between winter wheat yield/number of kernels per $\mathrm{m}^{2}$ and the traits of assimilation surface at anthesis and milky-wax ripeness (MWR) of grain of 10 varieties and 2 lines in growing season 2017/2018

\begin{tabular}{l|c|c|c}
\hline \multirow{2}{*}{\multicolumn{1}{c|}{ Traits of canopy assimilation surface }} & Stage & \multicolumn{2}{c}{$\begin{array}{c}\text { Correlation coefficient with standard } \\
\text { deviation (SD) }\end{array}$} \\
\cline { 3 - 4 } & & with yield & $\begin{array}{c}\text { with number } \\
\text { of kernels per } \mathrm{m}^{2}\end{array}$ \\
\hline $\begin{array}{l}\text { Fresh weight of green leaves of winter wheat plants per } \\
\mathrm{m}^{2}\end{array}$ & Anthesis & $\begin{array}{c}0.69 * * \pm 0.18 * \\
0.71 * * \pm 0.17\end{array}$ & - \\
Total chlorophyll content of green leaves & MWR & - & - \\
& Anthesis & MWR & - \\
Chlorophyll index of green leaves of winter wheat & Anthesis & $0.77 * * \pm 0.15$ & $0.62 * \pm 0.25$ \\
plants per $\mathrm{m}^{2}$ & MWR & $0.74 * * \pm 0.16$ & $0.64 * \pm 0.24$ \\
\hline
\end{tabular}

Note. Insignificant correlation; * and **- significant correlation, respectively, at $\mathrm{P}<0.05$ and at 0.01 . $\#$ : standard deviation.

seed mutagenized with ethylmethane sulphonate, had higher seed weights and grain yields per plant than the parental line, too [40]. Moreover it was also found that wheat variety Chuannong 17 carrying the wheat-rye 1BL/1RS translocated chromosome, which prolonged duration of active functioning of leaves, with higher rate of photosynthesis $\left(12.5-12.6 \mu \mathrm{mol} \mathrm{CO} / \mathrm{m}^{2} \mathrm{~s}\right)$, had a higher total grain weight per plant (12.4-13.0 g per plant), than control genotype Mianyang11 without the rye chromosome $\left(5.7-5.8 \mu \mathrm{mol} \mathrm{CO} / \mathrm{m}^{2} \mathrm{~s}\right.$ and $8.2-$ 8.9 g per plant, respectively) [41]. Significant (at the $\mathrm{P}<0.01$ ) correlation coefficients between rate of photosynthesis, as well as flag leaf area duration from anthesis to maturation and total grain weight per plant, confirms the positive effect of prolongation of the period of leaf functioning on the grain productivity. It was also found, that decrease in formation of photo assimilates in the period of grain filling or a change in source-sink balance led to decrease in yield. So, it was shown that an artificial shading of plants during period GS 55-61 reduced grain dry matter yield with $93 \mathrm{~g} / \mathrm{m}^{2}$, and during period GS $71-87$ with $281 \mathrm{~g} / \mathrm{m}^{2}$ [32]. Increase of source-sink ratios, when spikes were hand trimmed with 35-36\%, reduced grain yield with $23-40 \%$ at two different locations [35]. A considerable delay in flag leaf senescence, however, did not affect yield and kernel weight of transgenic lines of wheat with reduced expression of transcription factor homologs NAM-B1. In this case the authors [42] related it to the fact that in transgenic lines grain productivity was limited to the capability of grain to accumulate starch, and additional photo assimilates remained in stems, whereas in control plants they were re-mobilized for grain filling.

\section{CONCLUSIONS}

In our experiments, reported in this article it was established that the variability of traits of canopy assimilation surface in modern Ukrainian varieties and lines of winter wheat increased considerably in late stages of grain filling as compared to anthesis. A close positive correlation between the canopy assimilation surface capacity traits (leaf fresh weight of plants per unit area of canopy and the canopy leaves chlorophyll index) at milky-wax ripeness of 12 winter wheat genotypes was found under conditions of insufficient precipitation and elevated air temperature during the period, when the reproductive organs formed. A significant correlation between canopy leaves chlorophyll index at this stage and yield in years with other meteorological conditions was also established by us in a previous study [19]. Consequently, the data obtained in the present study further support the hypothesis that the maintenance of canopy photosynthetic activity at milky-wax ripeness is associated with an increased yield of winter wheat grown under different environmental conditions, including drought stress. The leaves fresh weight of canopy and canopy leaves chlorophyll index at milky-wax ripeness can be used as markers of grain productivity of winter wheat under drought stress, as well as for the possible development of molecular genetic criteria of breeding, based on these phenotypic characteristics.

The publication contains the results of studies, conducted in the framework of the project, financed by the Cabinet of Ministers: «Supporting the development of priority trends of scientific studies» (KPKVK 6541230). 
Взаємозв'язок між показниками потужності розвитку асиміляційної поверхні

та зернової продуктивністю генотипів озимої пшениці за умов посухи

В. В. Моргун, Г. О. Прядкіна,

О. О. Стасик, О. В. Зборівська

Інститут фізіології рослин і генетики НАН України, 03022 Київ, вул. Васильківська, 31/17

e-mail: galpryadk@gmail.com

Мета. Порівняльний аналіз параметрів асиміляційного апарату сортів і ліній озимої пшениці за умов підвищеної температури повітря та нестачі опадів у період закладки репродуктивних органів для пошуку ознак, пов'язаних 3 високою продуктивністю. Методи. Польовий, морфометричний, спектрофотометрический, статистичні. Результати. Максимальні відмінності по врожайності між сортами, що росли за умов недостатнього водозабезпечення в період закладки репродуктивних органів, становили майже $25 \%$. Найбільшою продуктивністю за таких умов характеризувалися нові сорти Почайна, Господарка і Київська 17, що сформували високий урожай 8,6-8,7 т/га та мають високі показники розвитку асиміляційної поверхні в розрахунку на одиницю площі посіву. Встановлено, що, в середньому, в фазу цвітіння найбільш врожайні сорти перевищували найменш урожайні на $30 \%$ по масі листків рослин 3 одиниці площі посіву, на $24 \%$ по вмісту хлорофілу і на $60 \%$ за величиною хлорофільного індексу. У фазу молочно-воскової стиглості відмінності між сортами істотно зростали - до $136 \%$ по масі листків рослин 3 одиниці площі посіву, 57 \% за вмістом хлорофілу і $350 \%$ за величиною хлорофільного індексу посіву. Виявлено тісну позитивну кореляцію показників потужності розвитку фотосинтетичного апарату посіву в репродуктивний період з урожайністю сортів і ліній озимої пшениці. Висновки. Отримані результати свідчать, що маса листків рослин з одиниці площі і хлорофільний індекс посіва у фазу молочно-воскової стиглості можуть бути використані в якості маркерів зернової продуктивності озимої пшениці, а також для розробки молекулярно-генетичних критеріїв селекції і оцінки генотипів озимої пшениці на високу продуктивність.

Ключові слова: Triticum aestivum L., асиміляційна поверхня посіву, хлорофільний індекс, урожай.

\section{Взаимосвязь между показателями мощности развития ассимиляционной поверхности и зерновой продуктивностью генотипов озимой пшеницы в условиях засухи}

В. В. Моргун, Г. А. Прядкина, О. О. Стасик, О. В. Зборовская

Институт физиологии растений и генетики НАН Украины, 03022 Киев, ул. Васильковская, 31/17

e-mail: galpryadk@gmail.com
Цель. Сравнительный анализ параметров ассимиляционного аппарата сортов и линий озимой пшеницы при действии неблагоприятных условий в период закладки репродуктивных органов для поиска признаков, связанных с высокой продуктивностью. Методы. Полевой, морфометрический, спектрофотометрический, статистические. Результаты. Максимальные различия по урожайности между сортами, которые росли в условиях недостаточного водоснабжения в период закладки репродуктивных органов, составляли почти $25 \%$. Наибольшей продуктивностью в таких условиях характеризовались новые сорта Почайна, Господарка и Киевская 17, сформировавшие высокий урожай 8,6-8,7 т/га и имеющие высокие показатели развития ассимиляционной поверхности в расчете на единицу площади посева. Установлено, что, в среднем, в фазу цветения наиболее урожайные сорта превышали наименее урожайные на 30 \% по массе листьев растений с единицы площади посева, на $24 \%$ по содержанию хлорофилла и на $60 \%$ по величине хлорофилльного индекса. В фазу молочно-восковой спелости различия между сортами существенно возрастали - до $136 \%$ по массе листьев растений с единицы площади посева, 57 \% по содержанию хлорофилла и 350 \% по величине хлорофилльного индекса посева. Обнаружена тесная положительная корреляция показателей мощности развития фотосинтетического аппарата посева в репродуктивный период с урожайностью сортов и линий озимой пшеницы. Выводы. Полученные результаты свидетельствуют, что масса листьев растений с единицы площади и хлорофилльный индекс посева в фазу молочно-восковой спелости могут быть использованы в качестве маркеров зерновой продуктивности озимой пшеницы, а также для разработки молекулярно-генетических критериев селекции и оценки генотипов озимой пшеницы на высокую продуктивность.

Ключевые слова: Triticum aestivum L., ассимиляционная поверхность посева, хлорофилльный индекс, урожай.

\section{REFERENCES}

1. Shiferaw B, Smale M, Braun H-J, Duveiller E, Reynolds $M$, Muricho G. Crops that feed the world 10. Past successes and future challenges to the role played by wheat in global food security. Food Sec. 2013;5:291317. doi: 10.1007/s12571-013-0263-y.

2. Atar B. Determination and assessments the yield gap between the wheat yield and potential yield in Turkey. Turkish Journal of Agriculture - Food Science and Technology. 2018;6(10):1339-46. doi: 10.24925/turjaf. v6i10.1339-1346.1825.

3. Lv Z, Liu X, Cao W, Zhu Y. A model-based estimate of regional wheat yield gaps and water use efficiency in main winter wheat production regions of China. Sci Rep. 2017;7(1):6081. doi: 10.1038/s41598-017-06312-x. 
4. Dhungana P, Eskridge KM, Baenziger PS, Campbell BT, Gill KS, Dweikat I. Analysis of genotype-by-environment interaction in wheat using a structural equation model and chromosome substitution lines. Crop Sci. 2007; 47(2):477-84. doi:10.2135/cropsci2006.06.0425

5. Grogan SM, Anderson J, Baenziger PS, Frels K, Guttieri MJ, Haley SD, Kim K, Liu S, McMaster GS, Newell M, Prasad PVV, Reid SD, Shroyer KJ, Zhang G, Akhunov E, Byrne PF. Phenotypic plasticity of winter wheat heading date and grain yield across the US great plains. Crop Sci. 2016;56(5):2223-36. doi:10.2135/cropsci2015.06.0357.

6. Parry MAJ, Reynolds M, Salvucci ME, Raines C, Andralojc PJ, Zhu XG, Price GD, Condon AG, Furbank $R T$. Raising yield potential of wheat. II. Increasing photosynthetic capacity and efficiency. J. Exp. Bot. 2011; 62:453-67.

7. Kiriziy DA, Stasik OO, Priadkina GO, Shadchina TM. Photosynthesis: $\mathrm{CO}_{2}$ assimilation and mechanisms of its regulation. Kyiv: Logos. 2014;2:480 p (in Russian).

8. Sadras VO, Calderini DF. Crop physiology: applications for genetic improvement and agronomy. Crop physiology. London, Academic Press. 2015:1-14. doi: 10.1016/B9780-12-417104-6.00001-7.

9. Foulkes MJ, Sylvester-Bradley R, Weightman R, Snape J. Identifying physiological traits associated with improved drought resistance in winter wheat. Field Crops Res. 2007;103(1):11-24. doi: 10.1016/j.fcr.2007.04.007.

10. Cattivelli L, Rizza F, Badeck FW, Mazzucotelli E, Mastrangelo AM, Francia E, Maré C, Tondelli A, Stanca $A M$. Drought tolerance improvement in crop plants: An integrated view from breeding to genomics. Field Crops Res. 2008; 105:1-14. doi: 10.1016/j.fcr.2007.07.004.

11. Chaves MM, Flexas J, Pinheiro C. Photosynthesis under drought and salt stress: regulation mechanisms from plant to cell. Ann. Bot. 2009;103(4):551-60. doi: 10.1093/aob/ men 125.

12. Farooq M, Hussain M, Siddique KHM. Drought stress in wheat during flowering and grain-filling periods. Critical Rev. Plant Sci. 2014;33(4):331-49. doi: org/10.1080/073 52689.2014.875291.

13. Nezhadahmadi A, Prodhan ZH, Faruq G. Drought tolerance in wheat. Sci. World J. 2013;1:610721. doi: 10. 1155/2013/610721.

14. Mwadzingeni L, Shimelis H, Dube E, Laing MD, Tsilo $T J$. Breeding wheat for drought tolerance: Progress and technologies. J. Int. Agric. 2016;15(5):935-43. https:// doi.org/10.1016/S2095-3119(15)61102-9.

15. Zheng TC, Zhang XK, Yin GH, Wang LN, Han YL, Chen L, Huang F, Tang JW, Xia XC,He Zhonghu. Genetic gains in grain yield, net photosynthesis and stomatal conductance achieved in Henan Province of China between 1981 and 2008. Field Crops Res. 2011;122(3):225-33. doi: 10.1016/j.fcr.2011.03.015

16. Furbank RT, Quick WP, Sirault XRR. Improving photosynthesis and yield potential in cereal crops by targeted genetic manipulation: prospects, progress and challenges. Field Crop Res. 2015;182:19-29. doi: 10.1016/j.fcr.2015. 04.009 .

17. Gregersen PL, Culetic A, Boschian L, Krupinska K. Plant senescence and crop productivity. Plant Molec. Biol. 2013;82(6):603-22. doi: 10.1007/s11103-013-0013-8.

18. Kipp S, Mistele B, Schmidhalter U. Identification of staygreen and early senescence phenotypes in high-yielding winter wheat, and their relationship to grain yield and grain protein concentration using high-throughput phenotyping techniques. Func. Plant Biol. 2014;41(3):227-35. doi: 10.1071/FP13221.

19. Priadkina GO, Maslyukivska OV, Stasik OO, Oksem VP. Relationships between leaves and canopy chlorophyll contents at grain filling and productivity of winter wheat. Plant Physiology and Genetics. 2015;47(2):167-74. http://nbuv.gov.ua/UJRN/FBKR_2015_47_2_9.

20. http://www.pogodaiklimat.ru/monotor.

21. Selyaninov GT. The origin and dynamics of droughts. Drought in the USSR. Their origin, repeatability and impact on the crop. By ed. AI. Rudenko. Leningrad, 1958:5-30 (in Russian).

22. Zadoks JC, Chang TT, Konzak CF. A decimal code for the growth stages of cereals. Weed Res. 1974;14:415-21. doi: https://doi.org/10.1111/j.1365-3180.1974.tb01084.x.

23. Wellburn AP. The spectral determination of chlorophyll $\mathrm{a}$ and $\mathrm{b}$, as well as carotenoids using various solvents with spectrophotometers of different resolution. J. Plant. Physiol. 1994;144(3):307-13. doi: 10.1016/S0176-1617 (11)81192-2.

24. Tarchevskiy IA, Andrianova YuE. The content of pigments as an indicator of wheat photosynthetic apparatus development power. Fiziologiya rasteniy. 1980; 27(2):341-47 (in Russian).

25. Dospehov BA. The method of field experience. Moskva: Agropromizdat. 1985;351 p (in Russian).

26. Liu EK, Mei XR, Yan CR, Gang DZ, Zhang YQ. Effect of water stress on photosynthetic characteristics, dry matte translocation and WUE in two winter wheat genotypes. Agric. Water Management. 2016;167(31):75-85. doi: https://doi.org/10.1016/j.agwat.2015.12.026.

27. Reddy AR, Chaitanya KV, Vivekanandan M. Droughtinduced responses of photosynthesis and antioxidant metabolism in higher plants. J. Plant Physiol. 2004; 161:1189-202.

28. Sharifi P, Mohammadkhani N. Effect of drought stress on photosynthesis factors in wheat genotypes during grain anthesis. Cer. Res. Comm. 2016;44(2):229-39. doi: 10.1556/0806.43.2015.054.

29. McDowell NG. Mechanisms linking drought, hydraulics, carbon metabolism, and vegetation mortality. Plant. Physiol. 2011;155(3):1051-59. doi: 10.1104/pp.110.170704.

30. Marček T, Hamow KÁ, Végh B, Janda T, Darko E. Metabolic response to drought in six winter wheat genotypes. PLoS ONE. 2019;14(2): e0212411. 
31. Farooq M, Wahid A, Kobayashi N, Fujita D, Basra SMA. Plant drought stress: effects, mechanisms and management. Agron. Sustain. Dev. 2009;29(1):185-212. doi: 10.1051/agro:2008021

32. Beed FD, Paveley ND, Sylvester-Bradley R. Predictability of wheat growth and yield in light-limited conditions. J. Agric Sci. 2007;145(1):63-79. doi: https://doi.org/10. 1017/S0021859606006678.

33. Sandaña PA, Harcha CI, Calderini DF. Sensitivity of yield and grain nitrogen concentration of wheat, lupine and pea to source reduction during grain filling. A comparative survey under high yielding conditions. Field Crops Res., 2009;114(2):233-43. doi: 10.1016/j.fcr.2009.08.003.

34. Xiao YG, Qian ZG, Wu K, Liu JJ, Xia XC, Ji WQ, He Zhonghu. Genetic gains in grain yield and physiological traits of winter wheat in Shandong Province, China, from 1969 to 2006. Crop Sci. 2012;52:44-56. doi: 10.2135/ cropsci2011.05.0246

35. Serrago RA, Alzueta I, Savin R, Slafer GA. Understanding grain yield responses to source-sink ratios during grain filling in wheat and barley under contrasting environments. Field Crops Res. 2013;150:42-51. doi: 10.1016/j. fcr.2013.05.016.

36. Reynolds MP, Pellegrineschi A, Skovmand B. Sink-limitation to yield and biomass: a summary of some investigations in spring wheat. Ann. Appl. Biol. 2005; 146(1):39-49. doi: https://doi.org/10.1111/j.1744-7348. 2005.03100.x.

37. Schnyder $H$. The role of carbohydrate storage and redistribution in the source-sink relations of wheat and barley during grain filling - a review. New Phytol. 1993;123(2):233-45. doi: https://doi.org/10.1111/j.14698137.1993.tb03731.x.

38. Ruuska SA, Rebetzke GJ, van Herwaarden AF, Richards $R A$, Fettell NA, Tabe L, Jenkins $C L D$. Genotypic variation in water-soluble carbohydrate accumulation in wheat. Funct. Plant Biol. 2006;33(9):799-809. doi: 10.1071/ FP06062.

39. Gepstein A, Banne I, Lifshitz Z, Blumwald E, Gepstein S. A new strategy for engineering drought tolerance in plant via auto-regulated expression of a key enzyme cytokinin synthesis. XVI Congress of the FESPB. 2008:p. S09-09, Tampere. doi: https://www.fespb.org/files/FESPB_2008_ ABSTRACT_BOOK.pdf

40. Spano G, Di Fonzo N, Perrotta C, Platani C, Ronga $G$, Lawlor DW, Napier JA, Shewry PR. Physiological characterization of «stay green» mutants in durum wheat. J. Exp. Bot. 2003;54(386):1415-20. doi: 10.1093/jxb/ $\operatorname{erg} 150$.

41. Luo PG, Zhan HY, Shu K, Wu XH, Zhang HQ, Ren ZL. The physiological genetics effects of 1BL/1RS translocated chromosome in «stay green» wheat cultivar CN17. Can. J. Plant Sci. 2009;89(1):1-10. doi: 10.4141/CJPS07072.

42. Borrill Ph, Fahy B, Smith AM, Uauy C. Wheat grain filling is limited by grain filling capacity rather than the duration of flag leaf photosynthesis: A case study using NAM RNAi Plants. PLoS One. 2015;10(8):e0134947. doi: https://doi.org/10.1371/journal.pone.0134947. 